\title{
Genomic variation and adaptation in Africa: implications for human evolutionary history and disease
}

\author{
Sarah A Tishkoff ${ }^{1,2^{*}}$, Michael Campbell ${ }^{1}$, Jibril Hirbo ${ }^{1}$, Joe Jarvis ${ }^{1}$, Wen-Ya Ko ${ }^{1}$, Charla Lambert ${ }^{1}$, Alessia Ranciaro ${ }^{1}$, \\ Laura Scheinfeldt', Sameer Soi ${ }^{1}$
}

From Beyond the Genome: The true gene count, human evolution and disease genomics

Boston, MA, USA. 11-13 October 2010

\begin{abstract}
Africa contains the greatest levels of human genetic variation and is the source of the worldwide range expansion of all modern humans. However, relatively little is known about genomic variation in ethnically diverse African populations. Knowledge of genetic structure within Africa has important implications for the design and implementation of disease association studies in Africans and in African Americans, and for reconstructing modern human origins. In addition, studies of genetic adaptation in Africa have important implications for identifying genes that play an important role in human evolution and disease. The African populations included in this study practice diverse subsistence patterns and have diverse diets (e.g. the study includes hunter-gatherers, pastoralists, agriculturalists and agropastoralists). The populations studied live in diverse environments with differing pathogen exposure (tropical forest, savannah, coastal, desert, low altitude and high altitude) and, therefore, are likely to have experienced local adaptation. In this talk I will discuss results of analyses of genome-scale microsatellite and SNP genotyping data in a large set of geographically, linguistically and ethnically diverse African populations, as well as locusspecific analyses of genes that play a role in adaptation to diet and infectious disease. Implications for future whole genome sequencing analyses will be discussed.
\end{abstract}

\section{Author details}

'Department of Genetics, University of Pennsylvania, Philadelphia, PA 19104-6145, USA. ²Department of Biology, University of Pennsylvania, Philadelphia, PA 19104-6145, USA.

Published: 11 October 2010

doi:10.1186/gb-2010-11-S1-I20

Cite this article as: Tishkoff et al:: Genomic variation and adaptation in Africa: implications for human evolutionary history and disease. Genome Biology 2010 11(Suppl 1):120.
Submit your next manuscript to BioMed Central and take full advantage of:

- Convenient online submission

- Thorough peer review

- No space constraints or color figure charges

- Immediate publication on acceptance

- Inclusion in PubMed, CAS, Scopus and Google Scholar

- Research which is freely available for redistribution

Submit your manuscript at www.biomedcentral.com/submit
Ciomed Central 